\title{
Devices and desires: industry fights toughening of medical device regulation in Europe
}

In the second paragraph of this Feature (BMJ 2013;347:f6204, doi:10.1136/bmj.f6204), we attributed the quote: "FDA-like system [that] would kill patients and kill innovative companies" to Eucomed and reference a Eucomed press release. However, the direct quote is not from Eucomed, but from "European investors" quoted in the release. According to the press release:
"Leading European investors have also cautioned that an 'FDA-like system would kill patients and kill innovative companies.",

Cite this as: BMJ 2013;347:f6325

๑ BMJ Publishing Group Ltd 2013 